\title{
Läti verbiprefiksite vastetest eesti keeles viie verbi näitel
}

\author{
ILZE TĀLBERGA， MERLE VARE \\ Tartu Ülikool
}

Ülevaade. Läti verbiprefiksid on üks keerukamaid grammatikateemasid läti keelt võõrkeelena õppijate jaoks. Raskust tekitab nii prefiksite tähenduse ja vajalikkuse mõistmine kui ka nende kasutamine. Olgugi et läti ja eesti keel on olnud tihedas kontaktis ja neid on mõjutanud samad võorkeeled, kuuluvad nad siiski erinevatesse keelkondadesse ning on mõistagi üsna erinevad. Eesti keeles verbiprefiksid puuduvad, mis on tõenäoliselt põhjuseks, et läti verbiprefiksitega on kimpus ka eestlastest keeleõppijad. Kuigi läti keele grammatikast kõneldes on püütud kaardistada verbiprefiksite funktsioonid (Ahero jt 1959; Soida 2009; Vulāne 2015a), puudub siiski ühtne ülevaade, millist tüüpi verbidega mis funktsiooni mingi prefiks kannab.

Käesoleva artikli eesmärk on uurida, kuidas verbiprefiksid muudavad verbi tähendust ja sellest tulenevalt, millised on läti verbiprefiksite vasted eesti keeles ning kas verbiprefiksi tähendust on üldse kuidagi väljendatud. Vaatluse all on viis erinevat verbi. Uurime, kuidas muudavad erinevad prefiksid põhiverbi tähendust, ja vaatleme, kas ja kuidas on prefiksiga kaasnev tähendusnüanss tõlgitud eesti keelde. Uurimismaterjaliks on näited läti ilukirjandusteostest, mida kõrvutame võrdlevalt eestikeelsete tõlgetega.

Võtmesõnad: võrdlev keeleuurimine; liikumisverbid; adverbid; prefiksid; ilukirjandustekstid; läti keel; eesti keel 


\section{Sissejuhatus}

Eesti emakeelega läti keele õppijatel on tihtipeale raskusi läti verbiprefiksite kasutamisega - üsna sageli ei teata, millisel juhul millist prefiksit konkreetse verbiga kasutada. Puudub terviklik ja kindel reeglistik, mille õppimisel võiks keeleõppija omandada verbiprefiksite kasutamise süsteemi. Teatud funktsioonide puhul, näiteks suuna markeerimisel ja esinemisel koos liikumisverbidega, on prefiks kindlamini aimatav ja abiks on, kui keeleõppija teab prefiksitele vastavaid prepositsioone, kui need on olemas, ja adverbe. Keerulisem on siis, kui arvestama peab ka muid tegevusega kaasnevaid näitajaid, näiteks kvantitatiivsust. Rohkusele viidates kasutatakse eesti keeles näiteks hulgamäärsõna palju, kuid läti keeles viitab puhtalt verbiprefiks sellele, et lauses Es sa-värīju kartupel̦us 'Ma keetsin kartuleid' oli keedetud kartulite kogus suur. See on justkui väike ja üldjuhul ehk ebaolulinegi lisateave, mis eestikeelses osasihitisega määramata hulka väljendavas lauses ei kajastu. Sääraseid marginaalse lisateabega näiteid on veelgi, ja kui läti keelest eesti keelde tõlkides sellise teabe esiletoomine ehk alati tarvilik polegi, siis läti keeles kõneldes märkavad lätlased sellist nüanssides eksimist kohe.

Läti keeles on 11 verbiprefiksit ja nende peamiseks funktsiooniks on muuta verbiga väljendatud tegevus lõpetatuks (perfektiivseks, resultatiivseks) ning enamasti anda verbi leksikaalsele tähendusele lisaks suunatähendus, ajaline või kvantitatiivne nüanss (Ahero jt 1959: 567; Kalnača 2014: 93-94; Kalnača 2015: 534). See tähendab, et prefiksita verb väljendab tavaliselt lõpetamata, kestvat (imperfektiivset, irresultatiivset) tegevust (Ahero jt 1959: 565-566; Paegle 2003: 130-131; Kalnača 2015: 534).

Eesti keeles puuduvad verbiprefiksid ja tegevuse lõpetatuse markeerimiseks kasutatakse võrreldes läti keelega teistsuguseid vahendeid, nt perfektiivsust (piiritletud situatsiooni) väljendatakse objektikäändega (täissihitis), perfektiivsusadverbidega, latiivsete määrustega, ajavormidega jne. Verbe jaotatakse imperfektiivseteks (nende seas ka partitiivverbid), perfektiivseteks ja aspektiverbideks. Kui sihiliste verbide puhul 
kannab üldjuhul perfektiivsuse ülesannet täisobjekt, siis sihitute verbide puhul, kui puudub afiksaaladverb, jääb see tõlgendus lahtiseks, nt Ta sõitis Brüsselisse. (Erelt 2017: 112-117)

Läti verbiprefiksite vasteid eesti keeles on uuritud täpsemini prefiksite ie- (Zagorska 2016) ja aiz- (Tālberga 2017) puhul. Samuti on uuritud läti ja eesti perfektiivse ja imperfektiivse aspekti väljendamist (Tālberga \& Mandel 2017). Nendest uurimustest selgub, et läti verbiprefiksite funktsioonid võivad eesti keeles olla väljendatud mitut moodi: afiksaaladverbidega, faasiverbidega, täisobjektiga, ahelverbiga jne, või ei avaldu need üldse. Samuti kinnitavad nimetatud uurimused, et prefiksiga väljendatud perfektiivsus võib eesti keeles olla märgatav üksnes lause tasandil, näiteks sihiliste liikumisverbide puhul perfektiivsuse väljendamine täisobjektiga. Sihitute verbide puhul ei pruugi perfektiivsus olla kajastatud ning tegevus võib olla kaheti mõistetav - imperfektiivne või perfektiivne -, kuid kumb, selgub laiemast kontekstist (Tālberga 2017: 238).

Käesoleva uurimusega jätkatakse läti verbiprefiksite funktsioonide vastete uurimist eesti keeles. Erinevalt eelmistest uurimustest, kus on vaadeldud konkreetseid prefikseid (Zagorska 2016; Tālberga 2017) ja nendega koos esinevaid verbe, keskendub käesolev uurimus sellele, kuidas muutuvad läti keeles konkreetsed verbid, kui neile liituvad erinevad prefiksid, ning kas prefiksitega verbe kõrvutades on eestikeelsete vastete vahel märgata erinevusi.

\section{Läti verbiprefiksid}

Verbiprefiksid kuuluvad verbi aspekti alla ning on peamiseks perfektiivse/imperfektiivse (lõpetatud/lõpetamata) aspekti väljendamise viisiks (Kalnača 2015: 533). Üldjuhul tähendab see seda, et prefiksita verb (nt braukt 'sõitma') on imperfektiivne ehk väljendab ajas kestvat tegevust (1), kuid prefiksiga verb (aizbraukt 'ära/minema sõitma') on perfektiivne ehk ajaliselt piiratud, mingi eesmärgini jõudnud (2) (Kalnača 2015: 533). Siiski ei pruugi prefiksi lisamine alati muuta verbi üksnes perfektiivseks, 
vaid tihtipeale kaasneb veel mõni tähendusnüanss. Nii lisab näites (2) prefiks aiz-verbile suunatähenduse [sõites eemalduma], mida eesti keeles saaks väljendada afiksaaladverbiga ära/minema, kuid näites (3) kaasneb prefiksiga at- vastupidise suuna tähendus 'siia/tagasi', mida eesti keeles väljendataks verbiga tulema ja adverbiga tagasi.

(1) viņš brauca uz laukiem

ta.NOM sõitma.PST.3 PREP maa.PL.DAT

'ta sõitis maale / ta oli teel maale'

(2) viņš aizbrauca uz laukiem

ta.NOM PREF-sõitma.PST.3 PREP Maa.PL.DAT

'ta sõitis (ära) maale'

(3) viņš atbrauca no laukiem

ta.NOM PREF-sõitma.PST.3 PREP maa.PL.DAT

'ta tuli maalt (tagasi)'

Liikumisverbidega koos esinedes omistatakse prefiksitele suunatähendus, mis kajastub prepositsioonides ja adverbides. Seitsmel prefiksil (aiz-, ap-, no-, pa-, pār-, pie-, uz-) on olemas vastavad prepositsioonid, erinevalt ülejäänud neljast ( $a t-, i e-, i z-, s a-)$, millel vastavaid prepositsioone vähemalt tänapäeva läti kirjakeeles pole (Soida 2009: 228; Mathiassen 1997: 159). Prepositsioonide eesmärk on täpsustada ja rõhutada prefiksiga väljendatud suunda (4) (Vulāne 2015b: 147).

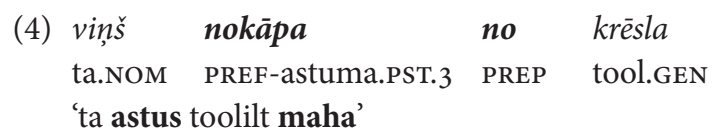

Igal prefiksil on suuna väljendamisel veel lisaks ka tugev seos adverbidega (Soida 2009: 236; Mathiassen 1997: 159). Nimelt vastab igale verbiprefiksile vähemalt üks adverb (vt tabelit 1) ning see, milline neist tähendustest on omane prefiksile, sõltub suuresti põhiverbi semantikast. Näiteks on prefiksil $u z$-adverbi virsū 'peale' või augša 'üles' tähendus ning sellest tulenevalt moodustuvad prefiksverbid: $u z$-krist 'peale kukkuma', $u z$-iet 'üles minema' jne. 
TABEL 1. Läti verbiprefiksitele vastavad adverbid (Ahero jt 1959: 571; Soida 2009: 236-242)

\begin{tabular}{|c|c|}
\hline Prefiks & Adverb \\
\hline aiz- & prom 'ära, minema, eemale', priekša 'ette', ciet 'kinni' \\
\hline$a p-$ & apkārt 'ümber', nost 'maha, ära' \\
\hline at- & šurp 'siia', nost 'maha, ära', atpakal 'tagasi', vaḷā 'lahti' \\
\hline$i e-$ & iekšā 'sisse' \\
\hline$i z-$ & $\bar{a} r a \bar{a}$, laukā 'välja'; cauri 'läbi' \\
\hline no- & lejup/lejā 'alla', zemē, nost 'maha, ära' \\
\hline$p a-$ & apakš( $\bar{a})$ 'alla', val̦ā 'lahti', garām 'mööda', sānis 'kõrvale' \\
\hline pār- & pāri 'üle', atpakal 'tagasi' \\
\hline pie- & klāt 'juurde, külge' \\
\hline sa- & kopā 'kokku', iekšā 'sisse', virsū 'peale', augšup 'üles' \\
\hline$u z-$ & virsū 'peale', augša 'üles' \\
\hline
\end{tabular}

Koos perfektiivsust väljendava prefiksiga võib tegevuse suunda rõhutada lisaks prepositsioonile veel ka substantiivi kääne (5) või prefiksile vastav adverb (6) (Paegle 2003: 134; Soida 2009: 236; Vulāne 2015a: 279). Oluline on meeles pidada, et prefiks väljendab samaaegselt nii tegevuse suunda kui ka perfektiivsust, seega kui näidetes (4), (5) ja (6) puuduks verbiprefiks, oleks tegevus tajutav kui kestev ning suund väljenduks üksnes prepositsiooni, substantiivi käände ja adverbi abil.

(5) viņa ieskrēja istabā ta.NOM PREF-jooksma.PST.3 tuba.LOC 'ta jooksis tuppa (sisse)'

(6) mès pārbraucām pāri tiltam meie.NOM PREF-sõitma.PST.PL1 üle sild.DAT 'me sõitsime sillast üle'

On tõenäoline, et prefiksid olid algselt seotud üksnes suuna väljendamisega, kuid aja jooksul tähendusväljad laienesid, teatud verbidega on prefiksitel suunatähendus kadunud ning asemele tekkinud muud 
funktsioonid (Ahero jt 1959: 567). On verbe, mille puhul on prefiksi funktsiooniks üksnes perfektiivsuse väljendamine ning muud lisatähendused ei ole tajutavad (Ahero jt 1959: 567).

Kui verbiprefiks ei väljenda otseselt suunda, võib selle ülesandeks olla mingil muul moel mõjutada verbi tähendust, nt kas väljendada puhtalt perfektiivsust (pirkt 'ostma' vs. no-pirkt ära ostma'), tegevuse algust (ziedēt 'õitsema' vs. uz-ziedèt 'õitsema lööma'), kvantiteeti (kurināt 'kütma' vs. pär-kurināt 'üle kütma') (Ahero jt 1959: 567; Paegle 2003: 130-131; Kalnača 2014: 93-94). Keeleõppijale tekitavad üldjuhul just need muud (nn abstraktsemad) funktsioonid kõige rohkem raskusi.

Prefiksverbid on tihti ka polüseemilised ning prefiksverbi tegelik tähendus võib avalduda üksnes kontekstis (Vulāne 2015a: 279). Näiteks võib verb saukt 'kutsuma' koos prefiksiga ie- esinedes väljendada suunda, kus prefiksile vastab adverb iekšā 'sisse' (7) ning konteksti loob substantiiv lokatiivis, või võib see väljendada tegevuse algust (8) ning konteksti loob prepositsioonifraas par + ACC.

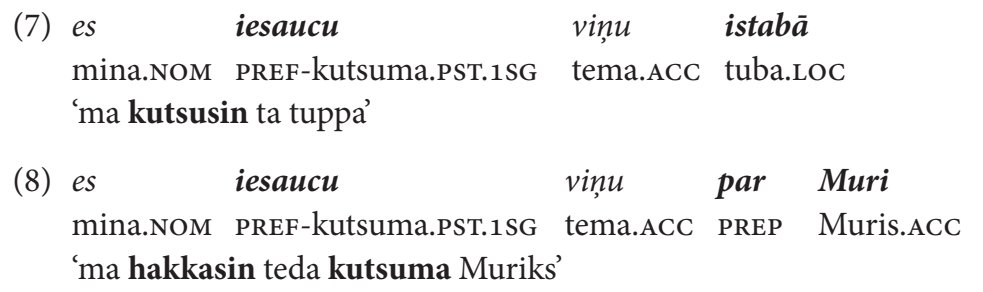

Tavaliselt kasutatakse ühe tegevuse väljendamiseks ainult ühte prefiksit, st verbile ei liitu korraga mitut prefiksit, välja arvatud eituse moodustamisel, nt ne-aiz-braukt 'mitte ära sõitma', või nende verbide puhul, millega prefiks on niivõrd liitunud, et verbi ja prefiksit ei tajuta enam eraldi üksustena (Ahero jt 1959: 345). Dzintra Paegle (2003: 132) ütleb selliste verbide kohta, et prefiksverb on omandanud prefiksita verbist oluliselt erineva tähenduse (stāvēt 'seisma' ja pie-stāvēt 'sobima') või ilma prefiksita verbi (enam) ei kasutata ( $p a-z \bar{t} t$ 'tundma').

Sama teema puhul jaotab Emīlija Soida (2009: 228-229) prefiksverbid derivatiivseteks ja formaalseteks prefiksverbideks. Derivatiivsed on 
sellised prefiksverbid, kus põhiverbi ja prefiksverbi vahel on tugev seos: prefiks annab põhiverbile mõne tähendusnüansi, nt liikumisverbi vest 'viima' tuletised aiz-vest 'ära viima', ap-vest 'viima ümber (mille)' jne. See tähendab, et prefiks modifitseerib verbi mingil moel (nimetatud näites muutub suund). Formaalseteks nimetab Soida neid prefiksverbe, millel on põhiverbiga üksnes formaalne seos, semantiline seos on kas väga nõrk või puudub üldse. Näiteks toob ta verbid turēt 'hoidma' ja uz-turēt 'ülal pidama'. See tähendab, et kuigi põhiverb on sama ja verbisemantika on üsna lähedane, ei vastandata neid verbe üldjuhul teineteisele ehk $u z$ turēt ei ole traditsioonilises mõttes verbi turēt perfektiivne vorm. Keeleõppija jaoks võib hoopiski küsitav olla semantiline seos prefiksverbi pār-baudìt 'kontrollima' ja verbi baudìt 'nautima' vahel.

Seega, kuigi prefiksita ja prefiksiga verbi vahel võib näha mingisugust semantilist seost, on need justkui kaks erinevat verbi. Soida (2009: 219) sõnul "[p]refiksverbide leksikaalse tähenduse moodustamisel ilmneb kaks tendentsi: 1) põhiverbi leksikaalne tähendus säilitatakse, seda veidi moduleerides, 2) põhiverbi leksikaalset tähendust muudetakse oluliselt ja see individualiseeritakse". Seega mõjutab prefiks alati mingil moel verbi tähendust, kuid mismoodi täpselt, sõltub mitmest asjaolust: verbi semantikast, kontekstist jne.

Suuna väljendamine paistab olevat ainus funktsioon, mille puhul võib tajuda konkreetseid sarnasusi eesti keelega: eestikeelsete vastete hulgast leiab adverbid ja kaassõnad, mis vastavad läti verbiprefiksite antud suunatähendusele (nagu need on toodud tabelis 1). Keerukam on tajuda prefiksi teisi funktsioone, kus seos suunaga puudub või on väga nõrk (vt verbi just 'tundma’ näiteid ja analüüsi peatükis 4.5).

\section{Materjal ja meetod}

Uurimuse tarbeks kasutati kakskeelset korpust, mille moodustavad kuus läti ilukirjandusteost ja nende eestikeelsed tõlked (vt allikate loetelu). Materjali uurimiseks kasutasime kontrastiivset meetodit - kõrvutasime lätikeelsed prefiksverbidega laused nende eestikeelsete tõlgetega. 
LÄt I VERBIPREFIKSITE VAstetest Eesti KEELES VIIE VERBI NÄITEL

Analüüsimiseks valisime viis verbi: iet 'minema', vest 'viima, vedama', dot 'andma', prast 'oskama' ja just 'tundma'. Verbide valik oli üsna vaba, kuid tegemist on sagedasti kasutatavate verbidega. Eesmärk oli mitte keskenduda üksnes liikumisverbidele ja näidata, et prefiksite valikul ei saa lähtuda üksnes prefiksite suunatähendusest. Arusaadavalt ei kajasta siinne andmestik kõiki võimalikke prefiksite tähendusnüansse ning esindatud pole ka kõik prefiksitele vastavad adverbid, kuid need näited annavad vähemalt aimu prefiksitega seotud keerukusest.

Vaatasime, kuidas muutub põhiverbi tähendus, kui sellele liituvad erinevad prefiksid. Otsisime vastust küsimusele, kas ja kuidas väljendatakse läti prefiksite vahetudes põhiverbi ees tähenduslikku muutust eesti keeles.

Prefiksite funktsioonide kirjeldamisel toetusime peamiselt kolmele allikale: 1959. aastal välja antud läti kirjakeele grammatikale (Ahero jt 1959), 2015. aastal välja antud läti grammatikale, kus verbiprefiksite peatüki autoriks on keeleteadlane Anna Vulāne, ning 2009. aastal ilmunud läti keeleteadlase Emīlija Soida monograafias "Vārddarināšana" ("Sõnamoodustus") käsitletud prefiksite tähenduste kirjeldamisele. Kui nendes allikates pole vastavat prefiksverbi mainitud, siis vaatasime seda läti üldsõnastikust ehk tesaurusest (TEZ).

Näidete hulga ja kvaliteedi suhtes tuleb rõhutada nii mõndagi olulist tõika. Uurimismaterjal pakub piiratud koguses näiteid, st näidete hulk ja verbide valik sõltub sellest, kas ja milliseid verbe on autorid oma loomingus kasutanud. On verbe, mida teoste autorid on kasutanud ainult mõnes konkreetses kontekstis, kuid tegelikult võib neil verbidel koos sama prefiksiga olla sõltuvalt kontekstist rohkem tähendusi. Niisama oluline tahk on tõlkija(te) subjektiivne keelekasutus: näiteks on tõlkimisel kasutatud semantiliselt erinevat tüüpi verbi või väljendit, või on jäetud mõni prefiksiga kaasnev tähendusnüanss või koguni terve lause tõlkimata. Ühtlasi on tegemist siiski ilukirjandusega, mis on läbinud toimetamise ja seetõttu ei pruugi anda täpseid verbiprefiksi vasteid. Võib oletada, et tõlkija(d) ei ole alati pööranud tähelepanu, ei ole tajunud või pidanud tähtsaks prefiksite funktsiooni ülekandmist eesti keelde, ning 
on seega lähtunud üksnes verbi prefiksita tähendusest. Meie eesmärk pole teha tõlkeanalüüsi, vaid lihtsalt vaadelda, milliseid vasteid esines.

\section{Empiiriline analüüs}

Uurimismaterjalist kogusime 38 prefiksverbi, mis esinesid kokku 1312 korral. Viiest uuritud verbist esines kõigi 11 prefiksiga verb iet 'minema', kuid verbid dot 'andma' ja vest 'vedama, viima' esinesid 10 prefiksiga, verb prast 'oskama' 5 prefiksiga ning verb just 'tundma' 2 prefiksiga (vt tabelit 2).

Kõik verbid ei esinenud kõikide prefiksitega kahel põhjusel: 1) peamiselt seetõttu, et verbi semantikast tulenevalt ei saa vastavat prefiksverbi moodustada, 2) kuigi prefiksverbi saab moodustada, ei esinenud see uurimismaterjalis. Prefiks ap- esines üksnes ühe verbiga, kuid prefiks $i z$ - ja $s a$ - kõigi viie verbiga.

Tabel 2. Uurimismaterjalis vaadeldud verbid ja nendega esinenud prefiksite arv

\begin{tabular}{|c|c|c|c|c|c|c|c|c|c|c|c|c|}
\hline Verb & $a i z-$ & $a p-$ & at- & $i e-$ & $i z-$ & no- & $p a-$ & $p \bar{a} r-$ & pie- & $s a-$ & $u z-$ & Kokku \\
\hline iet ' $\mathrm{m}$ & 63 & 7 & 3 & 84 & 67 & 4 & 50 & 35 & 45 & 11 & 18 & 387 \\
\hline vest 'viima' & 26 & - & 47 & 19 & 5 & 9 & 2 & 12 & 4 & 13 & 6 & 143 \\
\hline $\operatorname{dot}^{\prime} \mathrm{a}$ & 6 & - & 48 & 37 & 6 & 24 & 5 & 29 & 42 & 8 & 17 & 222 \\
\hline prast 'oskama' & - & - & - & - & 13 & 8 & - & 10 & 1 & 372 & - & 404 \\
\hline just 'tundma' & - & - & - & - & 46 & - & - & - & - & 110 & - & 156 \\
\hline Kokku & 95 & 7 & 98 & 140 & 137 & 45 & 57 & 86 & 92 & 514 & 41 & 1312 \\
\hline
\end{tabular}

\subsection{Verb iet 'minema'}

Verb iet 'minema' esines uurimismaterjalis kõigi 11 prefiksiga, kokku 387 korral (vt joonist 1). 


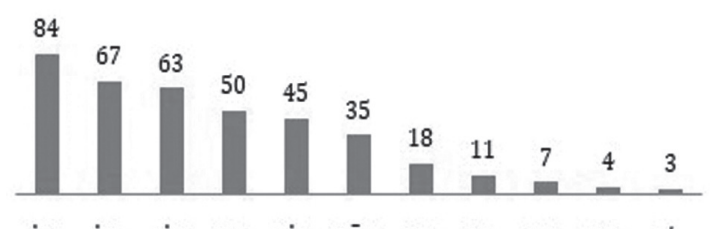

ie- iz- aiz- pa- pie- pār- uz- sa- ap- no- at-

Joonis 1. Verbiga iet 'minema' esinenud prefiksid ja nende arv

Tegemist on tüüpilise liikumisverbiga, mille puhul on prefiksitele selgelt omane adverbi tähendus. Populaarseim eestikeelne vaste oli ootuspäraselt lihtverb minema, millega kaasnes substantiiv prefiksi semantikale vastavas suunda märkivas käändes (illatiiv, allatiiv või elatiiv), kaassõnaühend (kaassõnadega ümber, mööda, sisse, üle, juurde) või afiksaaladverb (mööda, sisse, välja, üles, ära, minema).

Kõige enam esines verb iet prefiksiga ie-, millele vastab adverb iekša 'sisse, sees'. Andmestikus oli sagedasim konstruktsioon ieiet + LOC (9), mille tõlkevasteks oli enamjaolt lihtverb (üldjuhul minema, aga ka astuma, jõudma, sisenema, saabuma), millele liitus sihtkohana substantiiv illatiivis.

\section{(9) Iegājām mājā.}

PREF-minema.PST.1PL maja.LOC

'Läksime majja.' (Bels 1977, 1979)

Konstruktsiooni ieiet + LOC vastena esines ka ühendverb sisse minema + ILL (10). Siin võiks eestikeelses lauses adverb ka olemata olla, ilma et vaste infoväli muutuks kitsamaks, kuna liikumise suuna annab edasi substantiivi käändevalik (illatiiv), kuid selle lisamine rõhutab tegevuse suunda veelgi ja lisab ehk teatud perfektiivsusnüansi.

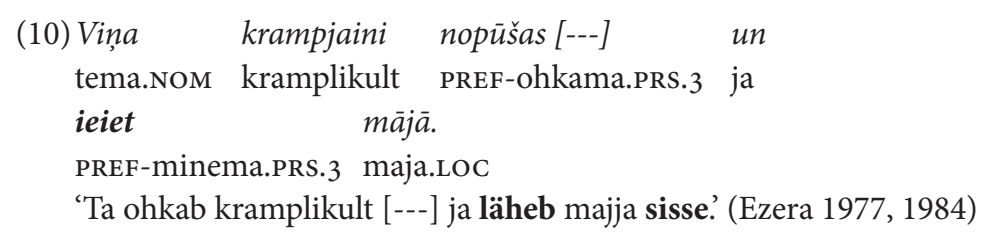


Kui lätikeelses lausekonstruktsioonis asendab sihtkohta märkivat substantiivi adverb iekšă 'sisse' (11), on eesti keeles vasteks ühendverb, mille üheks osiseks on adverb sisse.

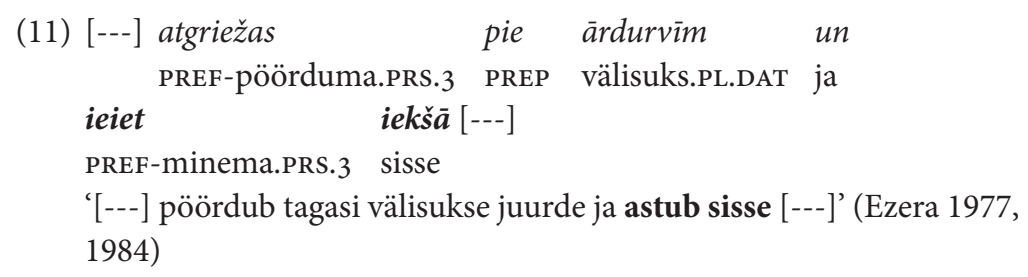

Uurimuses läti verbiprefiksi ie- vastete kohta eesti keeles (Zagorska 2016: 239-240) selgus, et kui sihtkohana pole substantiivi mainitud, esineb eestikeelse vastena ühendverb, mille verbaalset osist täiendab afiksaaladverb sisse, kui aga sihtkohta on mainitud, on vasteks ainult verb ja substantiiv illatiivis või allatiivis. Siinses uurimuses selgus, et ühendverb koos vastava afiksaaladverbiga võib esineda ka siis, kui läti keeles on sihtkohana substantiivi vastavas käändes nimetatud (10) ning kui prefiksverbile lisaks on kasutatud adverbi (11).

Prefiksile iz-vastav adverb on ārā, laukā 'välja' (Soida 2009: 239). Kui lauses polnud sihtkohana substantiivi märgitud, oli enamjaolt vasteks lihtverb väljuma (12) või lahkuma, kuid samuti ühendverb välja minema (13). Mõlemal puhul on välja(poole) liikumise suund edasi antud.

(12) Un Smirnovs izgāja, durvis aizcirzdams. ja Smirnov PREF-minema.PST.3 uks.PL.ACC PREF-lööma.PTCP '[---] hüüdis Smirnov ja väljus ust kinni lüües' (Rozītis 1957, 1984)

(13) Daktera nav mājās, viņš izgājis. doktor.Gen pole kodu.PL.LOC tema.NOM PREF-minema.PTCP 'Doktorit pole kodus, ta läks välja' (Rozìtis 1984, 1989)

Ainult ühendverbide abil olid eesti keelde tõlgitud laused, kus prefiksverbile liitus adverb laukā 'välja' (14) või ārā 'välja'. 
LÄt I VERBIPREFIKSItE VAstetest Eesti KEELES VIIE VERBI NÄITEL

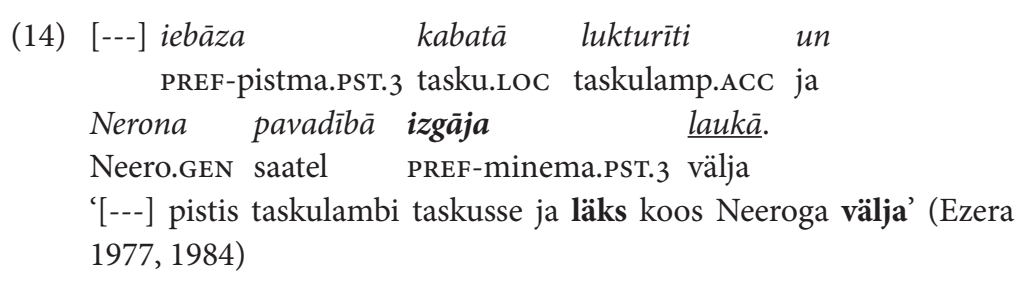

Kui lätikeelses lauses (15) oli prepositsiooni no abil mainitud lähtekoht ja puudus sihtkoht, kasutati tõlkimisel välja(poole) liikumise suuna edasiandmiseks verbi, mille semantikas selline suund kajastub (väljuma, lahkuma), või ühendverbi, mille adverbiaalne osis on välja.
(15) [---] uzlika galvā rūtaino žokejcepuri [---] PREF-panema.PST.3 pea.LOC ruuduline.ACC džokimüts.ACC un izgāja no $\underline{\text { zâles. }}$ ja PREF-minema.PST.3 PREP saal.gEN
'[---] pani pähe ruudulise džokimütsi [---] ja väljus söögisaalist' (Rozītis 1984, 1989)

Prefiks aiz- annab verbile iet liitudes tähenduse 'minnes eemalduma, minnes kuhugi jõudma, kaugenema' ning sellele vastav adverb on prom 'ära, minema, eemale’ (Ahero jt 1959: 345; Soida 2009: 237). Kui lätikeelses lauses (16) puudus sihtkohana substantiiv, oli eestikeelseks vasteks üldjuhul lihtverb lahkuma, mille semantikas on juba prefiksi tähendus olemas (vt ka Tālberga 2017).
(16) [---] vairījās raudzīties citiem acīs, ātri vältima.PST.3 vaatama.INF teine.PL.DAT silm.PL.LOC kiiresti paèda, piecēelās un aizgāja. PREF-SÖÖma.PST.3 PREF-tõusma.PST.3 ja PREF-minema.PST.3 '[---] vältis teistele silma vaatamast, sõi kiiresti, tõusis ja lahkus'. (Rozìtis 1984, 1989)

Kui lätikeelses lauses oli sihtkoha asemel nimetatud lähtekoht, avaldus ära liikumise suund eesti keeles selgelt afiksaaladverbide (ära, minema) abil, mida toetas elatiivi kääne (näites (17) aga ekstsessiivi vorm). 


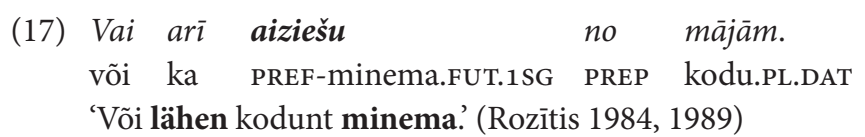

Üks prefiksile pa-vastav adverb on garām 'mööda (millest)' (Soida 2009: 240 ). Kuigi prefiksil $p a$ - on verbile iet liitudes ka suunatähendus (millegi alla liikumine) (Soida 2009: 240), hulga tähendus natuke (Vulāne 2015a: 282) ning tegevuse sooritamise suutlikkuse tähendus (lisanduks modaalverb varēt 'suutma') (Ahero jt 1959: 359; Soida 2009: 257), ei esinenud selliseid näitelauseid siinses materjalis. Meie andmestikus oli prefiksverbi paiet levinuimaks vasteks lihtverb mööduma (18), aga ka ühendverbid mööda minema/sammuma. Millestki füüsiliselt möödumist märkivates lausetes lisandus lätikeelses lauses adverb garām 'mööda (millest)' (19). Seega väljendub liikumisverbi paiet mööda minemise tähendus selgelt.

$\begin{array}{lll}\text { (18) Un tā pagāja } & \text { apmèram gads [--- } \\ \text { ja nii } & \text { PREF-minema.PST.3 } & \text { umbkaudu } \\ & \text { aasta.NOM }\end{array}$ 'Nii möödus umbkaudu aasta aega [---]' (Ezera 1977, 1984)

(19) Viņš no jauna pagāja garām skvēram, tema.NOM uuesti PREF-minema.PST.3 mööda haljak.DAT tad skolai [---] siis kool.DAT

'Uuesti möödus ta haljasalast, seejärel koolimajast [---]' (Ezera 1972, 1990)

Prefiks pie- annab liikumisverbile iet lisandudes adverbi klät 'juurde, külge' tähenduse (Ahero jt 1959: 362; Soida 2009: 240). Lätikeelses lauses toetab prefiksit prepositsioon pie ning eestikeelses tõlkelauses lisandub kasutatud lihtverbile kaassõna juurde (20).
(20) [---] viņa
tomèr piegāja pie Hugo [---] tema.NOM ometi PREF-minema.PST.3 PREP Hugo.GEN '[---] läks ta ometi Hugo juurde [---]' (Ezera 1977, 1984) 
Ligemale liikumise tähendus, mille annab samuti prefiksi pie- kasutamine, avaldus lätikeelsetes lausetes adverbi klāt 'juurde, külge' lisandumisel (21), sellisel juhul esinesid eestikeelses tõlkes adverbid lähemale, ligemale, mis moodustasid ühendverbi verbidega minema või astuma, või kasutati lihtverbi liginema.
(21) Pavisam nemanot bina bija üsna märkamatult tema.Nom olema.PST.3

Üks prefiksile $p \bar{a} r$ - vastav adverb on pāri 'üle' (Soida 2009: 240). Millestki üle liikumise suuna väljendamise puhul liitus prefiksverbile prepositsioon pār (22) või adverb pāri 'üle' (23) ning tõlkelausetes kasutati peamiselt verbi minema, aga ka sammuma ja ületama. Tähenduse 'liikudes kuhugi naasma' ehk adverbi atpakal 'tagasi' kohta kasutati vasteks lihtverbi jõudma.

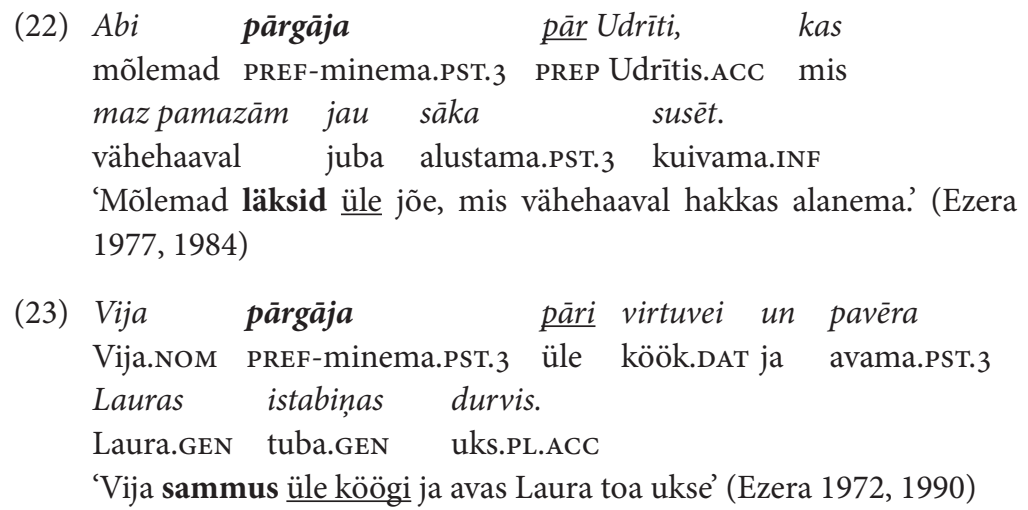

Meie uurimismaterjalis kasutati prefiksverbi pāriet kõige enam lausetes, milles väljendati mingi olukorra või nähtuse üleminekut, siirdumist (24). Sellise tähendusnüansi puhul oli enamjaolt vasteks ühendverb üle minema, kahel korral ka lihtverb mööduma. 
(24) Lietus pieñèmās, pārgāja gāzienā [---]

vihm.NOM tugevnema.PST.3 PREF-minema.PST.3 valing.LOC

'Vihm tugevnes, läks üle valinguks [---]' (Ezera 1972, 1990)

Prefiksile $u z$ - vastav adverb on augša 'üles' (Ahero jt 1959: 366; Soida 2009: 241) ja liikumisverbile iet lisandudes annab see üles(poole) liikumise suuna. Verbis minema ei avaldu üles(poole) liikumise suund kuidagi (25), kuid verbi tõusma liikumissuund on verbi enda semantikas. Kui aga läti keeles on samuti lisatud adverb augšà 'üles', on lause eesti keelde tõlgitud ühendverbiga üles minema (26).

(25) Kadviņš vakarā uzgāja savā

kui tema.NOM õhtu.LOC PREF-minema.PST.3 oma.LOC

istabin̄â, tad tur bija gaiši arī bez lampas.

tuba.LOC siis seal olema.PST.3 valge ka PREP lamp.geN

'Kui ta õhtul oma tuppa läks, oli seal valge ka ilma lambita.' (Rozītis $1957,1984)$
(26) Un, kad vina uzgāja augšā [---]
ja kui tema.NOM PREF-minema.PST.3 üles
'Ja kui ta üles läks [---]' (Ezera 1977, 1984)

Teine tähendus, mille prefiks $u z$-verbile iet annab, on '(liikudes) midagi juhuslikult avastama’ (27) (Vulāne 2015a: 286). Üldjuhul on vasteks lihtverb leidma või ühendverb peale sattuma, mis mõlemad annavad prefiksiga kaasneva tähendusnüansi kenasti edasi.
(27) Klē uzgāja dzelžu kasti [---] ait.LOC tema.NOM leidma.PST.3 raud.PL.GEN kast.ACC 'Aidast leidis ta kasti rauakoluga [---]' (Ezera 1972, 1990)

Prefiksile sa- vastav adverb on kopā 'kokku' (Soida 2009: 241). Meie andmestikus esinesid prefiksverbi saiet (28) vasted enamikul juhtudel fraseologismidena (minema + tülli, riidu, segi).
(28) Kautkad vienreiz tas taču iesākās, un kunagi ükskord see.NOM ju PREF-algama.PST.3 ja


LÄt I VERBIPREFIKSITE VAStetest Eesti KEELES VIIE VERBI NÄITEL

$\begin{array}{lll}\text { prāts } & \text { sagāja } & \text { greizi. } \\ \text { mõistus.NOM } & \text { PREF-minema.PST.3 } & \text { segi }\end{array}$

'Aga eks see ükskord ikka algas ja mõistus läks segi'. (Ezera 1977, 1984)

Prefiksile ap- vastav adverb on apkārt 'ümber' (Soida 2009: 238). Esinenud seitsmest näitelausest kuues väljendas prefiks $a p$ - suunda, ühes lauses avaldus tähendus 'tagaselja kellegi teadmata midagi tegema' (30). Suunda väljendavates lausetes toetas prefiksit tihtipeale prepositsioon ap (29) või adverb apkārt 'ümber'.

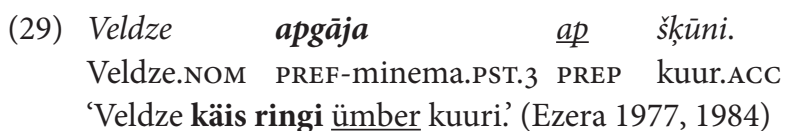

(30) Un Askolds, palicis priekšnamā viens, ja Askold.Nom jääma.PTCP esik.LOC üks.NOM jūtas kā apiets [---] tundma.PRs.3 nagu alt_vedama.PTCP.PST 'Askold on esikusse üksipäini seisma jäänud, tal on tunne, nagu oleks teda alt veetud [---]' (Ezera 1977, 1984)

Kõige harvem esinesid liikumisverbiga iet prefiksid no-, millele vastav adverb on lejup/lejā 'alla' (31) (Soida 2009: 239), ja at- (32). Viimase puhul esines näitelausetes nii suunafunktsioon ('tagasi liikudes (millestki) eemalduma') kui ka tähendus 'liikumist, sõitu alustama (transpordivahendi, hrl bussi, rongi jms kohta)'.

(31) Pats noiešu lejā un uzlaidī̌̌u ise.NOM PREF-minema.FUT.1SG alla ja PREF-laskma.FUT.1SG pateicības tiesu. tänu.GEN osa.ACC

'Lähen ise alla ja laon neile tänu turjale.' (Rozītis 1957, 1984)

(32) Vilciens uz Braitonu atgāja vakarā, [---] rong.NOM PREP Bridgetown.ACC PREF-minema.PST.3 õhtu.LOC 'Bridgetownie rong väljus alles õhtul.' (Rozītis 1984, 1989) 
Verbiga iet 'minema' esinesid kõik 11 prefiksit. Kuna tegemist on liikumisverbiga, võis lätikeelsete näidete puhul näha eelkõige seda, kuidas iga prefiks muudab verbi suunatähendust. Tihtipeale polnud eestikeelsetes tõlkelausetes vastavat suunda rõhutatud ja tõlgitud oli põhiverbi vastega minema (seda üle poolte kordadest). Kui aga suund oli väljendatud ka tõlkelauses, oli seda enamjaolt tehtud adverbidega, mis moodustasid verbaalse osisega ühendverbe. Paljudel puhkudel avaldus suunafunktsioon ka tõlkevasteks oleva verbi semantikas (lahkuma, väljuma, mööduma), kuid mõnda neist verbidest kasutati lihtverbi vastena erinevate prefiksite puhul. Perfektiivsuse funktsioon ei pruugi alati olla väljendatud.

\subsection{Verb vest 'viima, vedama'}

Verb vest 'viima, vedama' on üsna tavaline sihiline liikumisverb, mis esines uurimismaterjalis 10 prefiksiga (puudu oli prefiks ap-), kokku 143 korral (vt joonist 2).

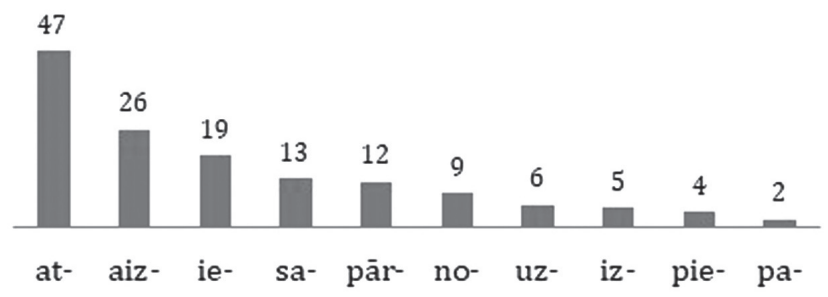

Joonis 2. Verbiga vest 'viima, vedama' esinenud prefiksid ja nende arv

Kõige enam esines vest prefiksiga at- adverbi siia funktsioonis, kandes tähendust 'siia toimetama' (33). Sõltumata prefiksverbi ümbrusest lätikeelses lauses, kasutati tõlkelauses siia-suuna väljendamiseks enamjaolt lihtverbi tooma, mida võib pidada põhiverbi tõlkevaste viima antonüümiks, ning perfektiivsus avaldus täisobjektina. 
LÄt I VERBIPREFIKSItE VAstetest Eesti KEELES VIIE VERBI NÄITEL

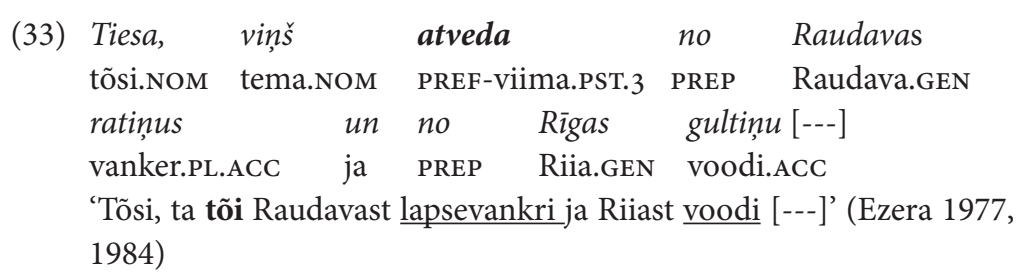

Vähestel kordadel lisandus verbile tooma adverbiaalne osis (kaasa, tagasi, kohale), kuid nendel puhkudel ei erinenud lätikeelne lause lausetest, mille tõlkevasteks oli adverbita konstruktsioon. Üksikutes näidetes oli tõlkevastetena kasutatud ka verbe toimetama, viima ja vedama (kas siis lihtverbina või ühendverbina koos juba nimetatud adverbidega).

Prefiksiga aiz-, mis märgib liikumisverbide puhul eemaldumise suunda, esines tõlkevastena enamjaolt lihtverb viima, üksikutel kordadel ka vedama ja toimetama. Erinevalt prefiksist at- oli lätikeelsetes lausetes üldjuhul märgitud sihtkoht, selle puudumisel on tõlkevasteks ühendverb ära viima (vt ka Tālberga 2017: 237-238)

Ka prefiksi ie- puhul oli vastena kasutatavaim verb viima, mis lihtverbina esinedes vastas lätikeelsetele lausetele, kus sihtkohta märkis substantiiv lokatiivis (34). Adverbi iekšā 'sisse' lisandudes ja suuna puududes lisandus kasutatud verbile (variantidena ka vedama, seadma, tooma) adverb sisse, ühel puhul ka juurde. Seega käitub ka verb vest prefiksi $i e$ - lisandumisel sarnaselt liikumisverbiga iet.

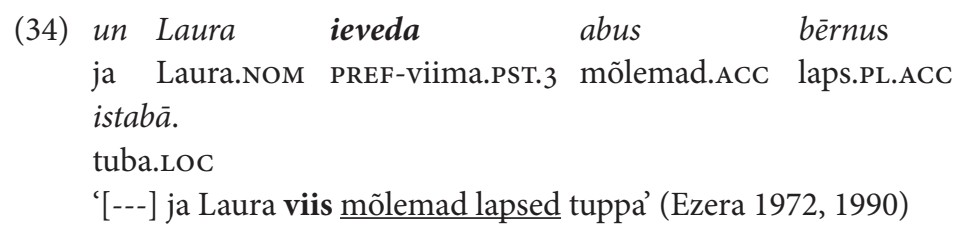

Esinemissageduselt järgmist prefiksit $s a$ - oli lauseis kasutatud (ühte kohta) kokku viimise/toomise suuna märkimiseks, suure hulga väljendamiseks, aga ka fraseologismides. Kokku-suuna väljendamisel võis lätikeelses lauses lisanduda prefiksile $s a$ - vastav adverb kopā 'kokku', kuid sellest sõltumata kasutati vastava suuna väljendamiseks tõlkelausetes üldjuhul ühendverbi kokku tooma/viima/vedama. Lauses (35) on näha, 
kuidas lisaks suunale motiveerib prefiksi $s a$ - kasutust ka kogus (hein loendamatu ja üldiselt suur hulk) ja tulemus (kogu hein saab küünidesse mahutatud), vrd näitega (34).

(35) Ap liepu ziedēšanas laiku, kad siens PREP pärn.PL.GEN õitsemine.GEN aeg.ACC kui hein.NOM savests šskūnos [---] PREF-viima.PTCP küün.PL.LOC 'Pärnade õitsemise ajal, kui hein oli küünidesse veetud [---]' (Rozītis 1984, 1989)

Fraseoloogilisi üksusi lõi prefiksverb savest substantiiviga kartība 'kord' lokatiivis (36), andes eestikeelseks vasteks väljendverbi korda löömal seadma/saamaltegema.

(36) [---] kamēr tad nu beidzot ciknecik savests kuni siis nüüd lõpuks enam-vähem PREF-viima.PTCP $\underline{k a ̄ r t i ̄ b a ̄ . ~}$

kord.LOC

' [---] kuni lõpuks oli enam-vähem korda saadud'. (Ezera 1977, 1984)

Prefiks pār- annab verbile vest liitudes tähenduse 'naasmine lähtepunkti või koju' (Ahero jt 1959: 360) või kannab adverbi pāri 'üle' tähendust (Soida 2009: 240). Meie materjalis esines ainult esimene funktsioon (37). Üldjuhul oli vasteks lihtverb tooma, nagu ka prefiksi at- puhul, aga esines ka ühendverbe (siia/tagasi/ära tooma) ning fraas vedama koju, kus substantiiv koju võiks asendada ühendverbi adverbiaalset osist (kui vastavas lätikeelses lauses pole sihtkohana kodu mainitud).

(37) Pirmajā miera vasarā viņš pārveda esimene.LOC rahu.GEN suvi.LOC tema.NOM PREF-viima.PST.3 no sila veselu baru mežonīgu govju [---] PREP laas.GEN terve.ACC kari.ACC metsik.PL.GEN lehm.PL.GEN 'Esimesel rahusuvel vedas ta laanest koju terve karja metsistunud lehm [---]' (Rozìtis 1984, 1989) 
Prefiksiga no- olid esindatud kaks funktsiooni: füüsilise sihtkoha olemasolul näitas no- allapoole liikumise suunda (38), selle puudumisel väljendas prefiks no- mingisse seisundisse või mingi tulemuseni jõudmist (39). Tõlkevastetena esinesid lihtverbid viima, vedama, juhtima, ühendverb kaasa tooma, adverbi lejā 'alla' olemasolul ka ühendverb alla viima.

(38) Kad

kui

Erika Laucim palīdzēja istabinu

Erika.NOM Laucis.DAT aitama.PST.3 tuba.ACC

iekārtot, noveda lejāpie akas un

PREF-korrastama.INF PREF-viima.PST.3 alla PREP kaev.GEN ja

pamācija üdeni smelt [---]

PREF-õpetama.PST.3 vesi.ACC ammutama.INF

'Kui Erika Laucisel tuba korrastada aitas, tema alla kaevu juurde viis ja vett ammutama õpetas, [---]’ (Rozïtis 1957, 1984)

(39) [---] ka noputējušajā

stiklā rādās

et PREF-tolmuma.PCPT.LOC klaas.LOC näitama.PRS.3

pagātnes ainas, kas vinu atkal gandriz

minevik.GEN pilt.PL.NOM mis tema.ACC jälle peaaegu

noveda līdz asarām.

PREF-VIima.PST.3 PREP pisar.PL.DAT

'[---] et tolmunud klaas näitas pilte minevikust, mis viis ta jälle peaaegu pisarateni' (Rozītis 1984, 1989)

Prefiksiga $u z$ - oli andmestikus väljendatud suund (üles(poole) viimise suund). Sihtkoha kõrgemal/üleval asumine avaldus lause kontekstis (pööning, mööda treppe), ühel korral viitas sellele adverb augšā 'üles' (40).

(40) Ja uzradās kāds provinces piegādātājs,

kui ilmuma.PST.3 mõni.NOM provints.GEN varustaja.NOM

to uzveda augšā dzīvoklī [---]

see.ACC PREF-viima.PST.3 üles korter.loc

'Kui ilmus mõni varustaja provintsist, viis José ta ülakorrusele [---]'

(Rozītis 1984, 1989) 
Ka prefiks $i z$ - väljendas ainult suunda. Prepositsiooni no olemasolul oli eesti vasteks ühendverb välja viima, lihtverbiliste (vedama, tooma) vastete puhul väljendus lätikeelses lauses suund lause kontekstis.

Prefiksiga pie- esinesid kaks funktsiooni. Kahes lauses oli väljendatud millegi juurde viimise suunda ning lätikeelses lauses toetas prefiksverbi prepositsioon pie. Mõlemas lauses oli see tõlgitud verbiga viima ning suuna andis kaassõna juurde. Vastava prepositsiooni puudumisel oli verbi tähenduseks 'midagi või kedagi millegi varustama' ja tõlkevasteks lihtverb tooma.

Prefiksil $p a$ - on verbile vest lisandudes järgmised funktsioonid: suund ('millegi alla'), kvantiteet ('natuke, lühikest maad viima'), individualiseerunud tähendus ('võrgutama') (TEZ). Meie andmestikus esinenud kahes lauses oli verbil pavest individualiseerunud tähendus (41).

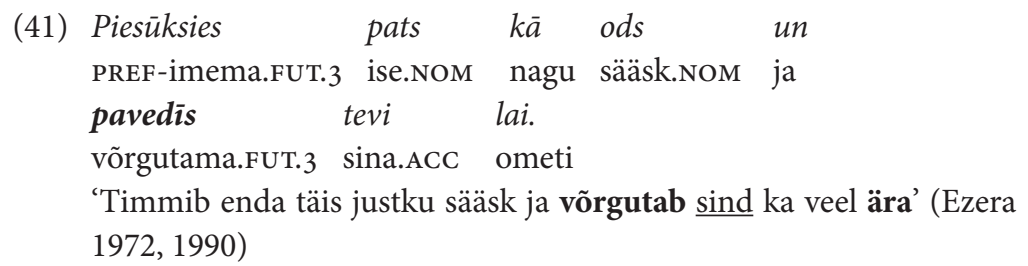

Sarnaselt liikumisverbiga iet 'minema' muutub verbi vest 'viima, vedama' tähendus erinevate prefiksite lisandumisel peamiselt suuna osas. Prefiksverbide vastetena esinevad põhiverbi vasted viima, vedama, tooma, kuid erinevalt verbist iet on siin vasteteks rohkem ühendverbe, milles prefiksi suunda väljendavad vastavad adverbiaalid. Kuna tegemist on sihilise verbiga, siis erinevalt sihitust verbist iet on verbi vest puhul võimalik perfektiivsuse funktsiooni väljendada täissihitisega.

\subsection{Verb dot 'andma'}

Kokku esines verb dot 'andma' 10 prefiksiga (puudusid näited prefiksiga ap-) 222 korda (vt joonist 3). 


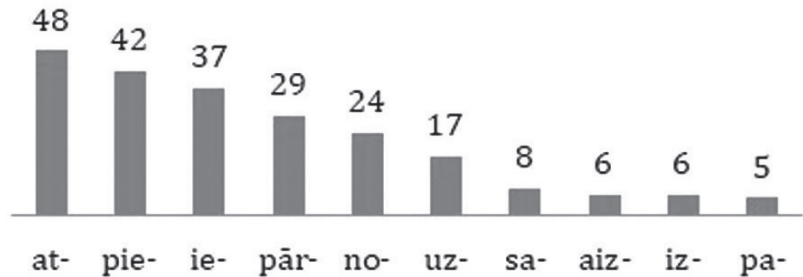

Joonis 3. Verbiga dot 'andma' esinenud prefiksid ja nende arv

Tähendus liigub suunalt üle abstraktsemale. Ainsad prefiksid, mis verbile dot liitudes väljendasid puhtalt suunda, olid at- tähenduses 'tagasi', $i z$ - tähenduses 'välja' ning no- tähenduses 'edasi andma'. Mitmel korral on prefiksid verbile omistanud individuaalse tähenduse, see tähendab, et kuigi põhiverbi dot 'andma' semantika on prefiksverbides tajutav, on need siiski justkui eraldi sõnad: aizdot 'laenama', pārdot 'müüma' (Ahero jt 1959: 347, 360). Iseseisev tähendus on tajutav ka eestikeelsetes vastetes.

Prefiksil pie- on kaks tähendust, millest ülekaalukalt enam esines individualiseerunud tähendus 'andeks andma, andestama' (42) ning üksnes paaril korral tähendus 'olemasolevale lisaks' (43), mida väljendab ka prefiksile pie- vastav adverb klät 'juurde, külge'.

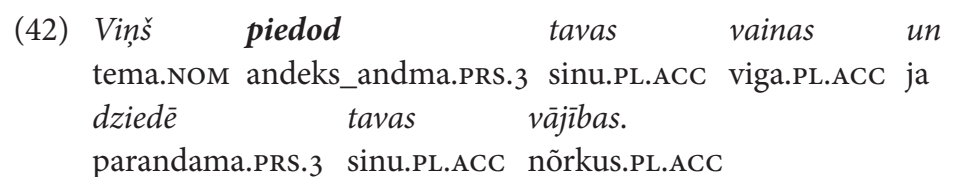

'Ta annab andeks su vead ja parandab su nõrkused!' (Ikstena 1998, 2003)

(43) Rūdolfs pārslēdza ātrumu, piedeva Rūdolf.NOM PREF-lülitama.PST.3 kiirus.ACC PREF-andma.PST.3 gāzi [---] gaasi.ACC 'Rūdolf lülitas kiiruse ümber, andis gaasi [---]' (Ezera 1972, 1990)

Prefiksi pa- puhul ei esine tüüpiline suunafunktsioon (alla(poole)), vaid sellel on pigem resultatiivsuse tähendus (Soida 2009: 252). See annab 
tähendusnüansi 'midagi ulatama, et keegi võiks selle kätte saada' (44) või kasutatakse seda tähenduses 'midagi teatavaks tegema' (45). Meie andmestikus esinesid eestikeelsete vastetena verbid ulatama (kättesaamiseks) ja andma (märku).

(44) Käds Eleonorai padeva mandel̦viestu, [---]

keegi.NOM Eleonora.DAT ulatama.PST.3 mandli_või.ACC

'Keegi ulatas Eleonorale mandli võid, [---]' (Ikstena 1998, 2003)

(45) Kad vini būs vajadzīgi, tadpados

kui nad.NOM olema.FUT.3 vajalik.PL.NOM siis PREF-andma. FUT.3

tikai ziņu, lai aulekšo šurp.

ainult teade.ACC las galoppima.PRs.3 siia

'Kui neid vaja läheb, siis annab ta ainult märku, et nad kohale kihutaksid.' (Rozītis 1957, 1984)

Esile tuleb tuua prefiksit $u z$-, mille põhitähenduseks üles(poole) suuna asemel on hoopis 'ülesandeks andma', 'kohustuseks tegema' ning mis väga sageli esineb koos substantiiviga jautājums 'küsimus' või $u z d e-$ vums 'ülesanne' (46). Ka meie andmestikus esines kõnealune prefiksverb peaaegu kõigis näitelausetes justnimelt koos nimetatud substantiividega. Sellistel puhkudel oli eesti vasteks (küsimust) esitama või ülesandeks andma. Nimetatud substantiivide puudumisel oli ikkagi vasteks ülesandeks tegema (47).

(46) Tavu jautājumu "Kas tie par svētkiem?" sinu.ACC küsimus.ACC mis need.NOM PREP püha.PL.DAT es sev uzdodu laikam katru dienu. mina.NOM endale esitama.PRS.1SG vist iga.ACC päev.ACC 'Sinu küsimust “Mis pühad need on?” esitan ma endale vist iga päev?' (Ikstena 1998, 2003)

(47) Man uzdeva jūs atvest šurp mina.DAT tegema_ülesandeks.PST.3 teie.ACC PREF-viima.INF siia un izmitināt, [---]

ja PREF-majutama.INF

'Mulle tehti ülesandeks teid siia tuua ja toita, [---]' (Rozītis 1984, 1989) 
Prefiks ie- annab verbile dot liitudes puhtalt perfektiivsuse tähenduse (Ahero jt 1959: 353; Soida 2009: 252) ja sellisel juhul on eesti keeles perfektiivsus väljendatud täisobjektiga (Zagorska 2016: 243). Peaaegu kõikidel juhtudel esineb vastena lihtverb andma (48). Meie andmestikus lisandus veel näide verb + täissihitis + kätte (49).

(48) $K a$

$\begin{array}{llccl}K \bar{a} \text { sauc } & \text { to } & \text { sievieti, } & \text { kas man } \\ \text { kuidas kutsuma.PRS.3 } & \text { see.ACC } & \text { naine.ACC } & \text { kes } & \text { mina.DAT } \\ \text { Tomaringos iedeva } & \text { laivu? }\end{array}$

Tomarini.LOC PREF-andma.PST.3 paat.ACC

'Mis selle naise nimi on, kes mulle Tomarinil paadi andis?' (Ezera 1972, 1990)

(49) Ar savu

$$
\text { ierašanos Latvijā } \quad \text { tu iedosi }
$$

PREP Oma.ACC ilmumine.ACC Lätimaa.LOC sa PREF-andma.

špikiem galus tieši rokā.

FUT.2SG nuhk.PL.DAT ots.PL.ACC otse käsi.LOC

'Oma ilmumisega Lätimaale annaksid sa nuhkidele otsad kätte.' (Rozīis 1984, 1989)

Prefiksi no- puhul oli suurem osa näitelausetes sisaldunud verbidest tähendusega 'reetma, ära andma' (50), nende eestikeelsed vasted olid lihtverb reetma või ühendverb ära/üles andma. Seos tüüpilise suuna väljendamisega (alla(poole) liikumise suund) puudub.

$$
\begin{aligned}
& \text { (50) Eleonora mani nenodeva, [---] } \\
& \text { Eleonora.NOM mina.ACC NEG.reetma.PST.3 } \\
& \text { 'Eleonora mind ei reetnud, [---]' (Ikstena 1998, 2003) }
\end{aligned}
$$

Prefiksverbil nodot on ka tähendus 'üle või edasi andma, esitama', kuid eestikeelsetes vastetes on ainult ühel korral kasutatud ühendverbi $e d a s i$ andma, ülejäänud näited on tõlgitud lihtsalt verbiga andma. Keeleõppijal on raske aimata tähenduslikku erinevust lausetes (48) ja (51). Nende konkreetsete näidete juures peab teadma, et prefiksi ie- puhul kuulub antav asi (paat) andjale ja see antakse kasutusse, no- puhul aga kaasneb tähendusnüanss 'esitama'. 
(51) Un kam tu nodevi pārrakstīto?

ja kes.DAT sina.NOM PREF-andma.PST.3 PREF-kirjutama.PTCP.ACC 'Ja kellele sa ümberkirjutatu andsid?' (Rozītis 1957, 1984)

Prefiksverbil sadot on peamiselt kolm tähendust: 'midagi suures koguses andma või midagi paljudele andma' (kvantitatiivsus), 'lööma, virutama’ või 'riidlema, tõrelema' (TEZ). Andmestikus esinenud näidetest ilmestas kvantitatiivsust vaid üks lause (52), ülejäänud olid seotud verbi sadot teise (53) ja kolmanda (54) tähendusega ning esinesid mõnel juhul fraseoloogilise väljendina. Kvantitatiivsuse näites (52) tingib lätikeelses lauses prefiksi sa- kasutuse väljend vesels kalns ('terve kuhi'). Eestikeelses tõlkelauses viitab suurele kogusele vaid nimetatud väljendi semantika, vastena esineb lihtverb andma.

(52) Jā, Osis manu algu pavisam apcirpa, jah Osis.NOM minu.ACC palk.ACC tublisti PREF-kärpima.PST.3 bet darba sadeva veselu $\underline{\mathrm{kalnu}}$. aga töö.GEN PREF-andma.PST.3 terve.ACC mägi.ACC 'Jah, Osis kärpis küll tublisti mu palka, kuid tööd andis terve kuhja' (Rozitis 1957, 1984)

(53) Ja tu tagad nebēgsi, es tev kui sina.NOM nüüd NEG.põgenema.FUT.2SG mina.NOM sina.DAT pašam labi sadošu! ise.DAT hästi PREF-andma.FUT.1SG

'Kui sa nüüd kohe ei põgene, virutan sulle endale!' (Rozìtis 1957, 1984)

(54) Tad jau laikam Marija sadeva sutu? siis juba vist Marija.NOM PREF-andma.PST.3 leitsak.ACC 'Eks vist Marija tegi sulle siis põrgut?' (Ezera 1972, 1990)

Võrreldes liikumisverbidega iet 'minema' ja vest 'viima, vedama' on verbil dot 'andma' rohkem individualiseerunud tähendusega esinemisjuhte: tekib uue tähendusega verbe ja seda on hästi näha just eestikeelsete vastete puhul. Seega lisandub suunafunktsioonile teisi, n-ö abstraktsemaid funktsioone. 
Järgmisena näitame, kuidas prefiksite suunatähenduse roll väheneb veelgi, kui tegemist pole liikumisverbiga.

\subsection{Verb prast 'oskama'}

Verb prast 'oskama' esines ainult viie prefiksiga ning kokku 404 korral (vt joonist 4).

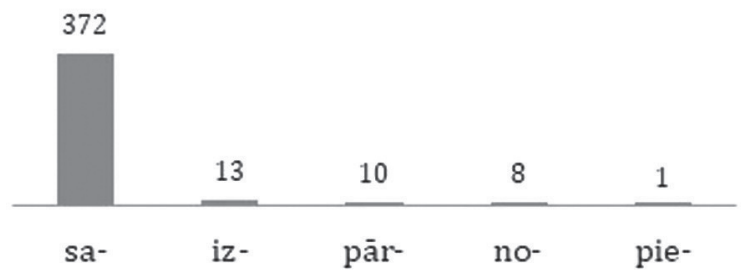

Joonis 4. Verbiga prast 'oskama' esinenud prefiksid ja nende arv

Verb prast 'oskama' ei ole liikumisverb, seega muutub ka sellega liituvate prefiksite seos suunaga hägusamaks. Prefiksverbi tähendused on põhiverbiga võrreldes individualiseerunud, seega on tegemist verbiga, mille puhul moodustub prefiksi lisandudes uus iseseisev tähendus.

Meie uurimismaterjalis esines ainult üks lause (55), kus prefiksil on põhiverbiga tugev seos ja see annab ainult tähendusnüansi, väljendades kvantitatiivsust ('natukene') (TEZ). See prefiks on pie-.

(55) Vecos laikos to piepratis itālis

vana.PL.LOC aeg.PL.LOC see.ACC PREF-oskama.PTCP itaallane.NOM Makiavelli, bet mūsu dienās vēl drusku Machiavelli.NOM aga meie.GEN päev.PL.LOC veel pisut mana sieva Nanija. minu.NOM naine.NOM Nanija.NOM 'Vanasti oskas seda itaallane Machiavelli, aga meie päevil veel pisut minu naine Nanija.' (Rozītis 1984, 1989) 
Prefiksi sa- liitudes on verbi leksikaalne tähendus individualiseerunud (Ahero jt 1959: 366), see tähendab seda, et prefiksverb saprast on iseseisev sõna ning prefiksil $s a$ - puudub konkreetne tähendus või funktsioon. Eesti keeles on prefiksverbi saprast vasteteks 'aru saama, mõistma, taipama' (56). Prefiksverb saprast oli ühtlasi kogu uurimismaterjalis kõige sagedasem verb.

(56) Ko $n u$ katrs ar to saprot [---] mida nüüd iga.NOM PREP see.ACC aru_saama.PRS.3 'Kuidas nüüd keegi sellest aru saab [---]' (Ikstena 1998, 2003)

Verb izprast tähendab 'täielikult mõistma, aru saama, lahti mõtestama' (Ahero jt 1959: 354). Selle eestikeelsed vasted kattusid enamjaolt prefiksverbi saprast vastetega (57).

(57) Taču vai man aizvien bija pietiekami

aga kas mina.DAT aina olema.PST.3 küllaldaselt

daudz vēlēšanās izprast citus?

palju tahtmine.GEN mõistma.INF teine.PL.ACC

'Aga kas mul oli alati küllaldaselt tahtmist teisi mõista?' (Ezera 1977, 1984)

Prefiksverbi noprast tähendus on 'enam-vähem mõistma, aru saama, aimama’ (58) ehk prefiks väljendab osalisust (Soida 2009: 248). Huvitaval kombel laiendab nii prefiks iz- kui ka no- justkui prefiksverbi saprast tähendust (midagi mõistusega haarama, taipama), mitte niivõrd verbi prast tähendust (mingi tegevuse tegemiseks oskusi/teadmisi omama). Ka tõlkevasted on prefiksverbidel saprast, izprast ja noprast enamjaolt samad.

(58) [---] bet stipri familiārais șāva kuid üsna familiaarne.NOM naeratus.NOM laskma.PST.3 noprast vēl ko citu[---] mõistma.INF veel mida muu.ACC ' [---] kuid üsna familiaarne naeratus laskis mõista veel muudki [---]' (Ezera 1977, 1984) 
Huvitava tõlkevaste pakub prefiksi pār- lisandumine verbile prast. Nimelt on selle prefiksiga väljendatud 'eksimise võimalust' (Ahero et al. 1959: 361) ehk kaasneb tähendus 'valesti mõistma, aru saama'. Sellisel puhul on prefiksi pār-funktsioon eesti keeles edasi antud viisimäärsõnaga valesti/vääriti, mis liitub lihtverbile mõistma või väljendverbile aru saama (59).

(59) Viņas sejas izteiksmes varēja viegli tema.GEN nägu.GeN ilme.PL.ACC võima.PRS.3 kergesti pārprast. valesti_aru_saama.INF

'Tema näoilmest võis kergesti valesti aru saada.' (Rozītis 1984, 1989)

Võrreldes verbidega iet 'minema', vest 'viima, vedama' ja dot 'andma' on selgelt näha, et verbi prast 'oskama' puhul loob prefiksiga tuletamine põhiverbist erinevaid verbe, sealjuures ei erine eestikeelsed vasted omavahel oluliselt, kuigi läti keeles on kasutatud erinevaid prefikseid.

\subsection{Verb just 'tundma'}

Verb just 'tundma' esines 156 korda ning ainult kahe prefiksiga (vt joonist 5).

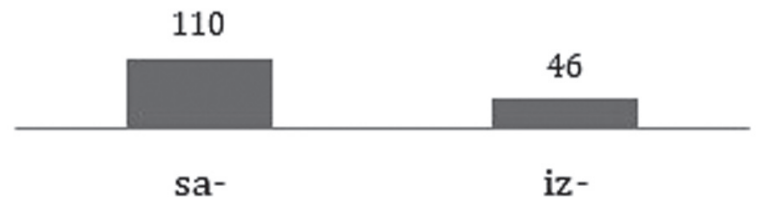

Joonis 5. Verbiga just 'tundma' esinenud prefiksid ja nende arv

Prefiksi $i z$ - tähenduseks on väljendada täielikkust ehk lõpetatust (Ahero jt 1959: 354). Läti keele üldsõnastiku (TEZ) järgi on verb izjust veidi rohkem emotsionaalne tunnetus (62), seevastu sajust on pigem füüsiline (61). Eestikeelsed vasted mõlema prefiksi puhul kattuvad ('tundma, tajuma, tunnetama'). Verbi izjust puhul esines materjalis vasteks veel 'läbi elama', mis ainsana annab tähenduslikult edasi emotsionaalset tunnetust. 


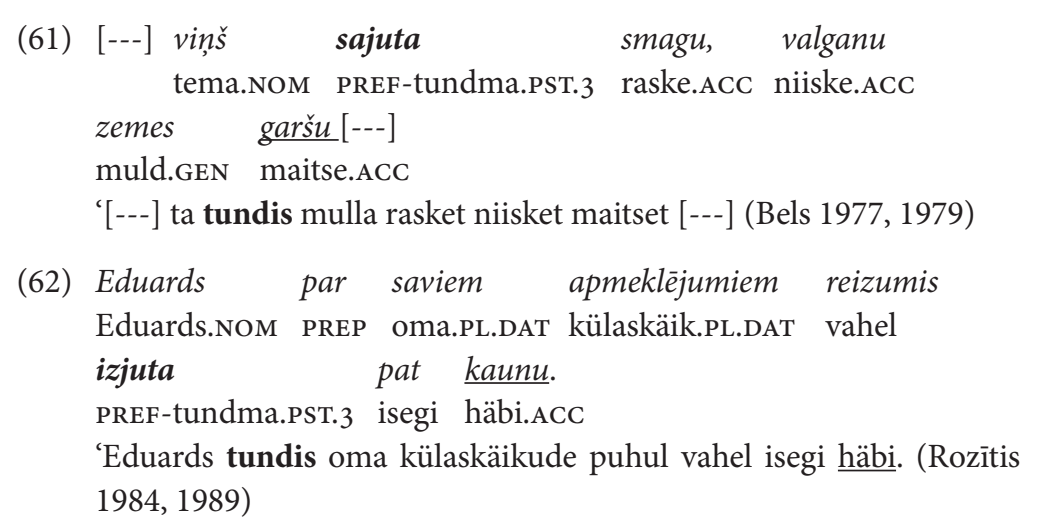

Verbi just 'tundma' puhul ei erine prefiksverbide vasted põhiverbi vastetest. Samamoodi ei erine omavahel eestikeelsed vasted, olgugi et läti keeles kasutatakse kindlatel puhkudel kas prefiksit $s a$ - või $i z$-.

\section{Järeldused}

Käesoleva uurimuse eesmärk oli vaadelda, kuidas muudavad erinevad verbiprefiksid sama verbi tähendust, millised on läti verbiprefiksite vasted eesti keeles ja kas verbiprefiksi tähendust on üldse kuidagi väljendatud. Varasemalt on uuritud prefiksite ie- ja aiz- (Zagorska 2016; Tālberga 2017) vasteid, ja neis kirjutistes selgus, et eestikeelseid vasteid on mitmesugusel kujul (liht-, ühend-, väljend-, ahelverb).

Käesolevas uurimismaterjalis esitatud prefiksite funktsioonid esindasid ainult väikest osa funktsioonidest, teoreetilistes allikates (Ahero jt 1959; Soida 2009; Vulāne 2015a) on neid nimetatud märksa rohkem. Kõikide funktsioonide väljatoomine ühes artiklis nõuaks tunduvalt rohkemate verbide analüüsimist, kuid loodame, et siinsed viis verbi annavad verbiprefiksite laiast teemast põgusagi ülevaate.

Tabelis 2 on näha, kuidas prefiksite esinemissagedus väheneb: verbiga iet 'minema' esinevad kõik läti keele 11 verbiprefiksit, verbidega vest 'viima, vedama' ja dot 'andma' 10 prefiksit, kuid verbiga prast 'oskama' 5 ja verbiga just 'tundma' üksnes 2 prefiksit. Mida vähem erinevaid 
prefikseid põhiverbile liitus, seda rohkem kaugenes prefiksite funktsioon suuna väljendamisest ja muutus hägusamaks. Seda illustreerib liikumisverbi iet 'minema' ja tajuverbi just 'tundma' võrdlus: esimene esineb kõigi prefiksitega ja igal prefiksil on suuna väljendamise funktsioon (lisaks perfektiivsusele), teine aga ainult kahe prefiksiga ning nendegi tähenduserinevus pole väga konkreetne, lisaks ei erine oluliselt eestikeelsed vasted.

Uuritud materjalis olid verbiprefiksite eestikeelseteks vasteteks peamiselt lihtverbid, millele lisandus verbi laiendav käändsõna kindlas käändes (nt illatiivis) või kaassõnafraas. Teise vastete rühma moodustasid analüütilised vormid: peamiselt ühendverb vastava afiksaaladverbiga, harvemal juhul väljendverb või fraseologism. Mõnel juhul kajastus prefiksi tähendus verbi semantikas (näiteks andis liikumisverbi puhul prefiksile iz-vastava adverbi ārā, laukā 'välja' tähenduse eesti keeles edasi verb väljuma). Väga paljudel juhtudel (nt verbi iet 'minema' puhul) polnud eestikeelses vastes suunda üldse edasi antud ja oli tõlgitud põhiverbi vastega (minema). Seega suudavad prefiksi lokaalset tähendust väljendada kõige paremini ühendverbid.

Läti keele õppimise seisukohalt on oluline rõhutada, et kõikidel prefiksitel on mitu funktsiooni (lisaks suunale). Tuleks uurida, mis tingib iga verbi puhul teatud funktsiooni väljendamiseks konkreetse prefiksi kasutuse. Keeleõppija jaoks on esmalt tähtis ära tunda, mis tüüpi verbiga on tegu. Kui on liikumisverb, võib üpris julgelt katsetada leida prefiksitele vasteid adverbide seast, mis annavad verbile suunatähenduse. Mida vähem on verbil seost liikumisega, seda kaugem on tõenäoliselt ka prefiksi seos suunaga.

Käesolevast uurimusest võime taas järeldada, et verbiprefiksite teema on üsna komplitseeritud ja nõuab veel edasist uurimist. 


\section{Lühendid}

1 esimese pöörde vorm

2 teise pöörde vorm

3 kolmanda pöörde vorm

ACC akusatiiv

DAT daativ

FUT tulevik

GEN genitiiv

INF infinitiiv

$\begin{array}{ll}\text { NEG } & \text { eitus } \\ \text { NOM } & \text { nominatiiv } \\ \text { PL } & \text { mitmus } \\ \text { PREF } & \text { prefiks } \\ \text { PREP } & \text { prepositsioon } \\ \text { PRS } & \text { olevik } \\ \text { PST } & \text { minevik } \\ \text { PTCP } & \text { partitsiip } \\ \text { SG } & \text { ainsus }\end{array}$

LOC lokatiiv

SG ainsus

\section{Allikad}

Bels, Alberts 1977. Poligons. Rīga: Liesma.

Bels, Alberts 1979. Polügoon. Valli Helde (Tõlk.). Tallinn: Eesti Raamat.

Ezera, Regīna 1972. Aka. Rīga: Liesma.

Ezera, Regīna 1990. Kaev. Valli Helde (Tõlk.). Tallinn: Eesti Raamat.

Ezera, Regīna 1977. Zemdegas. Rīga: Liesma.

Ezera, Regina 1984. Tuli tuha all. Valli Helde (Tõlk.). Tallinn: Eesti Raamat.

Ikstena, Nora 1998. Dzīves svinēšana. Rīga: Atēna.

Ikstena, Nora 2003. Elu pühitsus. Ita Saks (Tõlk.). Tallinn: Huma.

Rozìtis, Pāvils 1957. Valmieras puikas. Rīga: Latvijas Valsts izdevniecība.

Rozītis, Pāvils 1984. Valmiera poisid. Oskar Kuningas (Tôlk.). Tallinn: Eesti Raamat.

Skujinšs, Zigmunds 1984. Gulta ar zelta kāju. Rīga: Liesma.

Skujiṇš, Zigmunds 1989. Kuldjalaga voodi. Oskar Kuningas (Tõlk.). Tallinn: Eesti Raamat.

\section{Kirjandus}

Ahero, Antonija jt 1959. Mūsdienu latviešu literārās valodas gramatika I ['A Grammar of Modern Latvian']. Rìga: LPSR ZA izdevniecỉba.

Erelt, Mati 2017. Öeldis ['Predicate']. - Mati Erelt, Helle Metslang (Toim.). Eesti keele süntaks. Eesti keele varamu III. Tartu: Ülikooli Kirjastus, 93-239.

Kalnača, Andra 2014. A Typological Perspective on Latvian Grammar. Berlin: De Gruyter Open. https://doi.org/10.2478/9783110411317

Kalnača, Andra 2015. Darbības vārds (verbs) ['Verb']. - Ilze Auziṇa et al. (Eds.). Latviešu valodas gramatika. Rīga: LU Latviešu valodas institūts, 456-594. 
LÄt I VERBIPREFIKSITE VAStetest EestI KEELES VIIE VERBI NÄITEL

Mathiassen, Terje 1997. Short Grammar of Latvian. USA: Slavic Publishers, Inc.

Paegle, Dzintra 2003. Latviešu literārās valodas morfologija I ['Literary Latvian morphology I']. Zinātne.

Soida, Emīlija 2009. Vārddarināšana ['Word formation']. Rīga: LU Akadēmiskais apgāds.

Zagorska, Ilze 2016. Expressing the Latvian verb prefix ie- in Estonian. - Andra Kalnača, Ilze Lokmane, Daiki Horiguči (Eds.). Valoda: nozīme un forma. 7. Rīga: LU Akadēmiskais apgāds, 235-247. https://doi.org/10.22364/ VNF.7.19

Tālberga, Ilze 2017. Estonian equivalents of the Latvian verb prefix aiz-. - Andra Kalnača, Ilze Lokmane (Eds.). Valoda: nozīme un forma. 8. Valodas gramatiskās un leksiskās sistēmas variatīvums. Rīga: LU Akadēmiskais apgāds, 232-243

Tālberga, Ilze, Mandel, Aive 2017. On the imperfective and perfective aspect in Estonian and Latvian. - ESUKA/JEFUL 8 (1), 241-261. https://doi. org/10.12697/jeful.2017.8.1.13

TEZ = Tēzaurs. https://tezaurs.lv/ (22.8.2019).

Vulāne, Anna 2015a. Vārddarināšana ['Word formation']. - Latviešu valodas gramatika. Rīga: LU Latviešu valodas institūts, 190-299.

Vulāne, Anna 2015b. Afiksu raksturojums ['Description of Latvian affixes']. Latviešu valodas gramatika. Rīga: LU Latviešu valodas institūts, 146-153. 


\title{
Showing the correspondences of the Latvian verb prefixes in Estonian through five verbs
}

\author{
ILZE TÁLBERGA, MERLE VARE \\ University of Tartu
}

Latvian verb prefixes is one of the most difficult and complicated grammar topics for Estonians to comprehend and acquire. Since Estonian lacks verb prefixes, it is substantial to investigate and carry out a systematic overview of the possible equivalents of the Latvian verb prefixes in Estonian for the purpose of the better teaching and learning of both languages.

In Latvian verb prefixes are considered to be part of the verb aspect and in addition to the perfectiveness they may also variate the lexical meaning of the verb for example in spatial, temporal, or quantitative level (Ahero et al. 1959: 567; Paegle 2003: 130-131; Kalnača 2014: 93-94). Estonian, however, uses different measurements for the expression of aspect - object case, perfectivity adverbs, lative adverbials, time forms etc (Erelt 2017: 112-117).

In this article we introduce some of the basic correspondences of the Latvian verb prefixes in Estonian. The goal of the research was to analyse how Latvian verb prefixes change or modulate the meaning of the verbs and how and if these changes are expressed in Estonian. The data materials of this study are the examples taken from six Latvian literary works and their translations into Estonian. The analysis of the data material is done using a contrastive method we compared the Latvian sentences consisting of corresponding prefixed verbs to their Estonian translations.

The functions of the prefixes in this study material represented only a small part of the functions. You can clearly see how the meaning of the prefixes changes starting with a specific spatial meaning, and becoming more abstract. The fewer different prefixes joined the verb, the more the prefix function moved away from spatial and became more abstract. This is illustrated by the comparison of the movement of iet 'to go' and just 'to feel': the first verb is used with all prefixes and each prefix has a function of expressing the direction (in addition 
to perfection), but the last verb has only two prefixes, and their meaning difference is not very specific.

The correspondences of the verb prefixes in Estonian mainly consisted of a simple verb (+ substantive case, prepositional phrase). The second group of responses consisted of analytical forms: predominantly a compound verb with the corresponding affixal verb, in rare cases an expression verb or phraseology. In some cases, the meaning of the prefix was reflected in the semantics of the verb (for example, in the case of a movement, the prefix $i z$ - meaning adverb $\bar{a} r \bar{a}$ 'out' was carried out as Estonian verb väljuma). In many cases (eg verb iet 'to go') the response in the Estonian language was not forwarded at all and was translated into verb minema (to go) and the spatial meaning occurred only in the context. Thus, the local meaning of the prefix can best be expressed by compound verbs.

It is important to distinguish and emphasize when it comes to learning Latvian, when a prefix is obligatory when expressing an activity. Since all the prefixes have multiple functions, it is necessary to examine what causes a particular prefix to be used to express a certain function for each verb. For a language learner, it is first important to recognize what type of verb is involved. If there is a movement verb, it may be quite easy to try to find matches for the prefixes from the adverbs that give the verb meaning of spatiality. The less the verb is connected to the motion, the further the probability of the prefix is to be spatial. From this study, we can again conclude that the subject of verb prefixes is rather complicated and requires further investigation.

Keywords: contrastive linguistics; spatial verbs; adverbs; prefixes; fiction; Latvian; Estonian

\section{Ilze Tālberga}

Tartu Ülikooli eesti ja üldkeeleteaduse instituut

Jakobi 2, 51014 Tartu, Estonia

ilze.talberga@ut.ee

\section{Merle Vare}

Tartu Ülikooli eesti ja üldkeeleteaduse instituut

Jakobi 2, 51014 Tartu, Estonia

merle.mad@gmail.com 